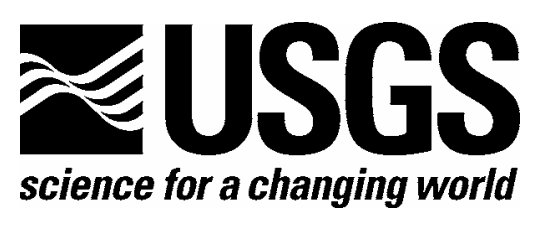

\title{
Geologic Map of the West Half of the Blythe 30' by 60' Quadrangle, Riverside County, California and La Paz County, Arizona
}

Compiled by Paul Stone ${ }^{1}$

Pamphlet to accompany

Scientific Investigations Map 2922

${ }^{1}$ U.S. Geological Survey, Menlo Park, California

2006

U.S. Department of the Interior

U.S. Geological Survey 


\section{INTRODUCTION}

This report presents a geologic map of bedrock and surficial geologic materials in the west half of the Blythe 30' by 60' quadrangle, which is located along the Colorado River between southeastern California and western Arizona. The map area is a desert terrain consisting of mountain ranges surrounded by extensive alluvial fans and plains. The flood plain of the Colorado River forms the east margin of the area. Mountainous parts of the area are underlain by rocks that range in age from Proterozoic to Miocene; these rocks record a complex geologic history that includes a major episode of Late Cretaceous deformation and metamorphism and Miocene detachment faulting. Surficial deposits of the flanking alluvial fans and plains range in age from late Miocene to Holocene and include deposits of the Colorado River in the eastern part of the area. Large parts of the area are covered by eolian sand.

The geologic map presented here was prepared as part of the U.S. Geological Survey's Southern California Areal Mapping Project, the area of which extends from the southern California coast inland to the Colorado River. The map is updated from the west half of a previously published, preliminary geologic map of the Blythe 30' by 60' quadrangle (Stone, 1990). The present map was compiled digitally, in contrast to the earlier analog map, and it contains more detailed information on the late Cenozoic surficial materials than the earlier map.

Bedrock geologic information on this map is only slightly modified from that presented by Stone (1990), which was compiled primarily from Hamilton (1964, 1984), Tosdal (1988), Stone and Pelka (1989), and Ballard (1990). Mapping of the late Cenozoic surficial deposits is based largely on interpretation of aerial photographs and recent field studies by the author. The field studies consisted of more than 350 site visits across the map area to document the lithologic character of the surficial deposits and to establish criteria for consistent identification of these deposits by examination of aerial photographs.

This pamphlet contains a simplified geologic map and cross section of the west half of the Blythe 30 ' by 60' quadrangle (figs. 1-3) to be used in conjunction with the full-size geologic map. The simplified map shows inferred traces of major subsurface structural features considered either too speculative or imprecisely located to show on the full-size map. The inferred subsurface features are based on regional structural correlations (Hamilton, 1984; Howard and John, 1987; Ballard, 1990; Tosdal, 1990; Richard, 1993) and gravity data (Rotstein and others, 1976; Mariano and others, 1986).

\section{GEOLOGIC FRAMEWORK AND HISTORY}

\section{Proterozoic Basement Rocks}

The oldest rocks in the map area are gneiss and granite of Proterozoic age (Hamilton, 1982, 1984; Tosdal, 1988; Powell, 1993). Most of the gneiss (Egn) is undated but presumably is Paleoproterozoic in age based on regional isotopic studies (Wooden and Miller, 1990). Augen gneiss in the Little Chuckwalla Mountains is dated as about 1650 to 1680 Ma (L.T. Silver, cited by R.E. Powell, written commun., 1989). The granite (Epg), much of which is metamorphosed to augen gneiss, is dated as about $1400 \mathrm{Ma}$ (L.T. Silver, oral commun. in Hamilton, 1982) and is part of an extensive belt of Mesoproterozoic granite complexes that extends across much of North America (Anderson, 1983). Proterozoic rocks in the northern parts of the Big Maria and Little Maria Mountains are mapped as part of an undivided unit of Proterozoic and Mesozoic gneiss (Mzegn).

\section{Paleozoic Sedimentary Rocks}

In the southern and central Big Maria Mountains and in the Little Maria Mountains, Proterozoic rocks are stratigraphically overlain by metamorphosed sedimentary rocks of Paleozoic age (Hamilton, 1982, 1984; Ballard, 1990). These rocks (MEs, PPs, P€s, Pzs) consist of quartzite, calc-silicate rocks, calcitic and dolomitic marble, and schist. Hamilton $(1982,1984)$ showed that these rocks, although highly

metamorphosed and deformed, constitute a sequence of well-defined stratigraphic units correlative with 


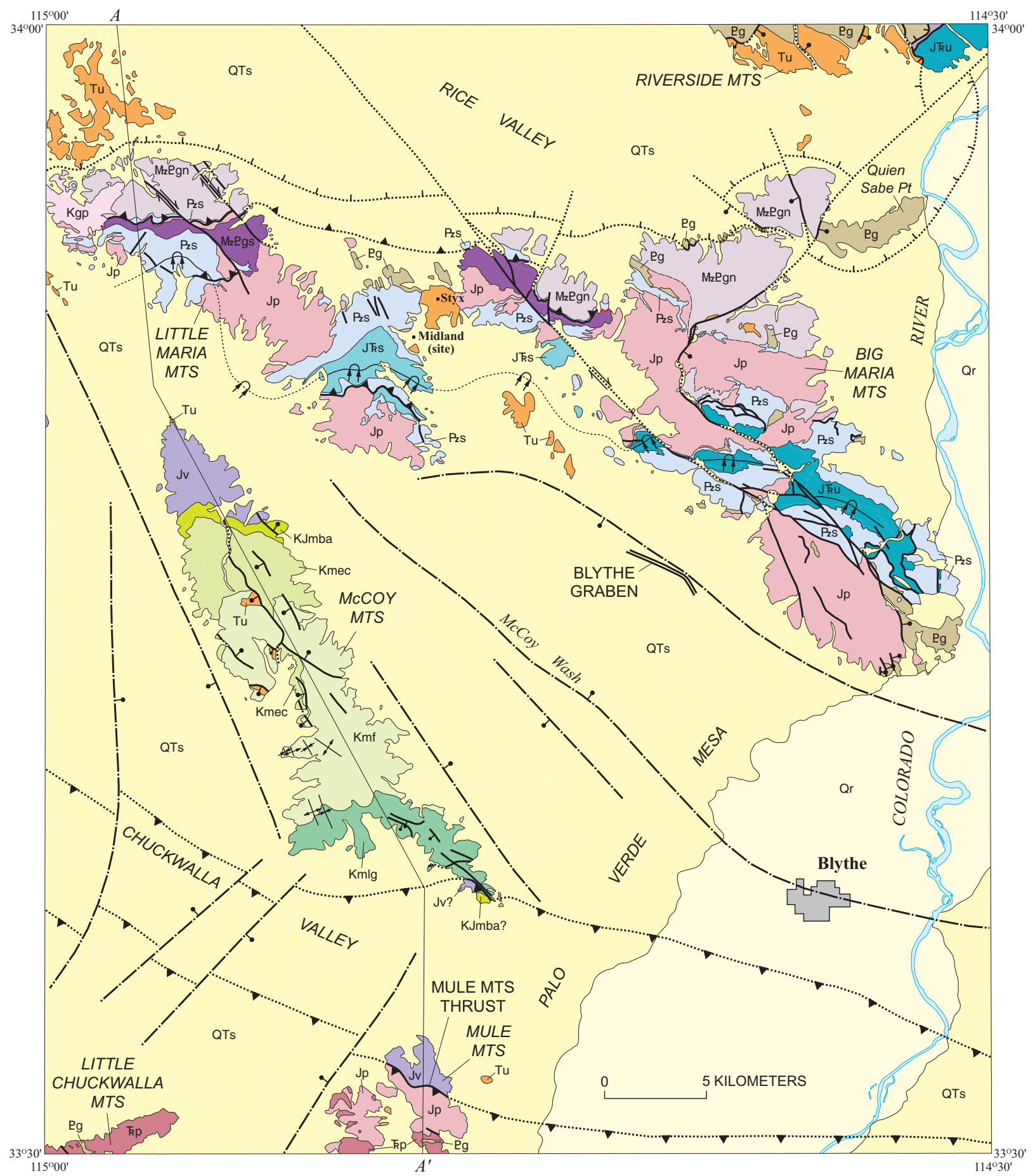

Figure 1. Simplified geologic map of west half of the Blythe 30'x60' quadrangle showing inferred traces of major subsurface structural features. See figure 2 for explanation of symbols and figure 3 for cross section $A-A^{\prime}$. Subsurface features based in part on data and interpretations of Rotstein and others (1976), Hamilton (1984), Mariano and others (1986), Howard and John (1987), Ballard (1990), Tosdal (1990), and Richard (1993). See text for further discussion. 
Alluvium of the modern Colorado River floodplain (Holocene)

Surficial deposits, undivided (Holocene to Miocene)

Tu

Kgp

$\mathrm{Kmf}$

$\mathrm{Kmec}$

KJmba

Jp

JV

Jku

JKS

kp

PzS

$\mathrm{Pg}$

Mzegn

MzPgs

Sedimentary and volcanic rocks, undivided (Miocene and Oligocene?)

Gneissic porphyritic granite (Cretaceous)

McCoy Mountains Formation (Cretaceous and Jurassic)

Members L to G (Cretaceous)

Member F (Cretaceous)

Members E to C (Cretaceous)

Members B and A (Cretaceous? and Jurassic)—Includes Cretaceous or Jurassic andesite in southern McCoy Mountains

Plutonic rocks (Jurassic)

Volcanic rocks (Jurassic)

Volcanic and sedimentary rocks, undivided (Jurassic and Triassic)

Sedimentary rocks (Jurassic and Triassic)

Plutonic rocks (Triassic)

Sedimentary rocks (Paleozoic)

Gneiss and granite (Proterozoic)

Gneissic rocks, undivided (Mesozoic and Proterozoic)

Gneiss and schist (Mesozoic or Proterozoic)

Fault - Bar and ball on downthrown side. Dotted where concealed

Fault - Arrows show apparent sense of lateral displacement. Dotted where concealed

ـ_...... Thrust fault - Teeth on upper plate. Dotted where concealed

$\perp \_$ــ........ Low-angle detachment fault-Hachures on upper plate. Dotted where concealed

- - L.L. Sul

Subsurface fault inferred from gravity data-Bar and ball on downthrown side (in direction of gravity low)

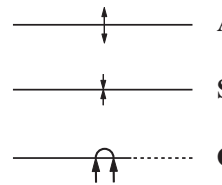

Anticline

Syncline

Overturned syncline-Dotted where concealed

Figure 2. Explanation of map units and symbols used in figure 1. 


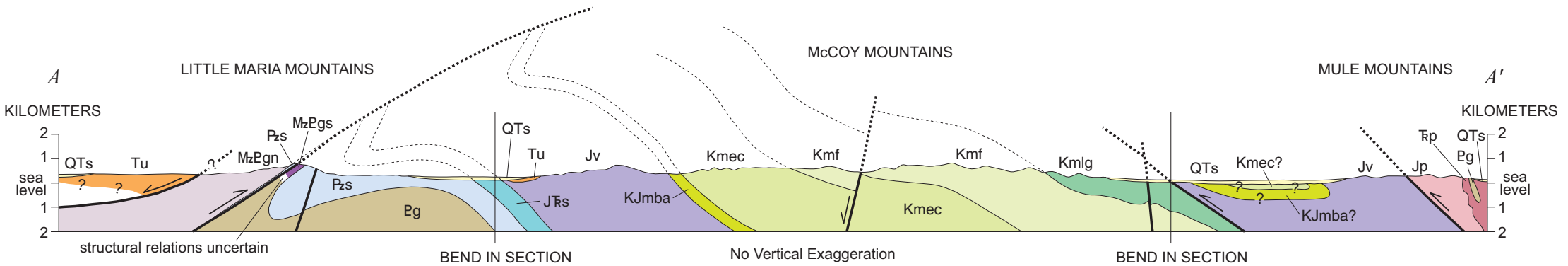

Figure 3. Structural cross section along line $A-A$ ' shown in figure 1. Contacts of Quaternary and late Tertiary surficial deposits (QTs) are generalized. Symbols as in figures 1 and 2. 
Cambrian to Permian formations of the Grand Canyon, Arizona, such as the Tapeats Sandstone, Redwall Limestone, and Kaibab Limestone. Accordingly, the map area was part of the western North American cratonal platform that was covered by shallow-marine waters throughout most of the Paleozoic.

Metamorphosed Paleozoic strata similar to those in the map area are scattered throughout much of the Mojave and Sonoran Deserts (Stone and others, 1983).

\section{Triassic and Jurassic Sedimentary Rocks}

Stratigraphically above the Paleozoic rocks is a sequence of metamorphosed clastic strata (JKs) that were deposited in shallow-water marine and nonmarine cratonal environments during the Triassic and Jurassic. These strata are composed of several rock types including gypsiferous schist, calcareous quartzite, orthoquartzite, and metaconglomerate (Hamilton, 1982, 1984; Ballard, 1990). Gypsiferous rocks in the lower part of the stratigraphic sequence probably are correlative with the Early and Middle Triassic(?) Moenkopi Formation; gypsum has been mined commercially from these rocks in the southeastern Little Maria Mountains near the abandoned townsite of Midland. The youngest unit, composed of locally crossbedded eolian quartzite, has been correlated with the Early Jurassic Aztec Sandstone (Hamilton, 1982), but more recently it has been interpreted as Middle Jurassic in age (Fackler-Adams and others, 1997). In places, this quartzite rests unconformably on the Permian Kaibab Limestone, apparently reflecting local erosion prior to deposition of the Jurassic eolian sand.

\section{Triassic Plutonic Rocks}

Plutonic rocks of Triassic and Triassic(?) age are exposed near the south edge of the map area in the Mule and Little Chuckwalla Mountains. These rocks include quartz monzonite and monzodiorite (Kqm) dated as about $213 \mathrm{Ma}$ in the Mule Mountains (Tosdal, 1988; Barth and others, 1990; Powell, 1993). Hornblende chemistry of the quartz monzonite-monzodiorite unit indicates a crystallization pressure of about $4.5 \mathrm{kbar}$, corresponding to a depth of approximately $17 \mathrm{~km}$ (Barth and others, 1990). It is unknown whether the intrusion of these deep-seated plutonic rocks was coeval with deposition of any of the early Mesozoic strata exposed in the northern part of the area, or whether the plutonic rocks were emplaced during a hiatus in deposition. More extensively exposed in the Mule and Little Chuckwalla Mountains is an older, but undated, unit of diorite and gabbro ( $\mathrm{kd}$ ) of questionable Triassic age (Tosdal, 1988; Barth and others, 1990; R.E. Powell, written commun., 1989; Powell, 1993). Barth and others (1997) have shown that rocks in the map area lie near the south end of an extensive Triassic plutonic belt that records the early stages of Cordilleran Mesozoic arc magmatism in eastern California and western Nevada.

\section{Jurassic Volcanic and Plutonic Rocks}

Most of the Jurassic rocks in the map area consist of variably deformed and metamorphosed volcanic and plutonic rocks. The volcanic rocks (Jv), which are considered part of the regionally extensive Dome Rock sequence of Tosdal and others (1989), are exposed in the Big Maria, McCoy, and Mule Mountains. In the Big Maria Mountains, this unit consists of highly deformed and metamorphosed volcanic rocks of intermediate to silicic composition that stratigraphically overlie Triassic and Jurassic metasedimentary rocks (Hamilton, 1982, 1984). Volcanic rocks in the McCoy and Mule Mountains are compositionally similar to those in the Big Maria Mountains but are less deformed and metamorphosed (Pelka, 1973; Tosdal, 1988; Stone and Pelka, 1989). Volcanic rocks in and near the map area have been dated as about 155 to $175 \mathrm{Ma}$ (Tosdal and others, 1989; Fackler-Adams and others, 1997; Barth and others, 2004) and are interpreted to have originated primarily as ash-flow tuffs. The Jurassic plutonic and metaplutonic rocks (Jp, Jpgd, Jpgb) are primarily granodiorite to quartz monzonite that form large intrusive masses in the Little Maria, Big Maria, and Mule Mountains (Hamilton, 1982, 1984; Tosdal, 1988; Ballard, 1990). These rocks are considered part of the Kitt Peak-Trigo Peaks super-unit of Tosdal and others (1989), which is dated as about 158 to $165 \mathrm{Ma}$. Jurassic volcanic and plutonic rocks broadly correlative with those of the map area are widespread in western North America and define a northwesttrending Andean arc (Saleeby and Busby-Spera, 1992). 


\section{Jurassic(?) and Cretaceous McCoy Mountains Formation}

Jurassic volcanic rocks in the McCoy Mountains are stratigraphically overlain by a very thick sequence of weakly metamorphosed and deformed sedimentary rocks assigned to the McCoy Mountains Formation (KJma-Kml). This formation, which has a stratigraphic thickness of about $8 \mathrm{~km}$, is composed mainly of fluvial sandstone and conglomerate derived from plutonic and volcanic source terranes (Pelka, 1973; Harding and Coney, 1985). The lower, predominantly quartzose members A and B of the McCoy Mountains Formation could be as old as Late Jurassic (Fackler-Adams and others, 1997), but most of the formation (members $\mathrm{C}-\mathrm{L}$ ) was deposited during late Early and Late Cretaceous time as indicated by analysis of detrital zircons (Barth and others, 2004). If members A and B are Late Jurassic, an intraformational disconformity must be present below member $\mathrm{C}$. Recent studies have suggested that the McCoy depositional basin formed in a complex tectonic setting south of an active, east-trending belt of deformation and behind (east of) the north-trending Cretaceous Cordilleran magmatic arc (Tosdal and Stone, 1994; Barth and others, 2004).

\section{Late Cretaceous Deformation and Metamorphism}

In Late Cretaceous time, the map area was the site of deformation and metamorphism in the Maria belt of Reynolds and others (1986) and Richard and others (1994). The most intense deformation and metamorphism are recorded in the Big Maria and Little Maria Mountains. There, Jurassic and older rocks were metamorphosed to temperatures of 400 to $600^{\circ} \mathrm{C}$ at pressures of 2 to $4 \mathrm{kbar}$ and ductilely deformed into a complex set of east-trending folds and nappes (Hamilton, 1982, 1984, 1987; Hoisch and others, 1988; Ballard, 1990; Richard and others, 1994). In the Little Maria Mountains (fig. 3), Paleozoic and early Mesozoic metasedimentary rocks are folded into a major, south-vergent overturned syncline beneath a thrust plate of Proterozoic and Mesozoic gneiss (Mzegn) in contact with a thin overturned sheet of Paleozoic rocks (Ballard, 1990). An intervening plate of fine-grained gneiss and schist (MzPfg and MzPs; MzEgs in figs. 13 ) is of uncertain age and structural significance ${ }^{1}$. An overturned syncline, possibly the same as the lowerplate syncline in the Little Maria Mountains (fig. 1), has been mapped continuously across the central Big Maria Mountains by Hamilton (1984). There, in the overturned limb of the syncline, the Paleozoic sedimentary sequence locally has been tectonically thinned to as little as 1 percent of its original stratigraphic thickness (Hamilton, 1982). The age of deformation is not precisely known, but thermochronologic data from the Big Maria Mountains indicate that peak metamorphism, which probably coincided with deformation, occurred shortly before $75 \mathrm{Ma}$ (Hoisch and others, 1988; Richard and others, 1994). Most of the deformation was postdated by intrusion of a granitic pluton (Kgp) exposed in the northeastern Little Maria Mountains; this pluton is considered part of the Late Cretaceous (about $70 \mathrm{Ma}$ ) Cadiz Valley batholith of Howard (2002).

Hamilton (1982), Ballard (1990), and several others including Ellis (1982) and Emerson (1982) have noted that most small-scale structural features in the Big Maria and Little Maria Mountains indicate a top-to-northeast direction of tectonic transport, in contrast to the apparent southward vergence of the major synclines. Hamilton (1982) interpreted all of the structural features, including the major synclines, as the product of a single, complex deformation representing northeast-directed overfolding and laminar flow. By contrast, Ballard (1990) attributed these small-scale structural features to late-stage, northeast-vergent extensional deformation following an earlier south-vergent contractional deformation that produced the major synclines. The cross section presented in this report (fig. 3) is consistent with the interpretation of Ballard (1990).

\footnotetext{
${ }^{1}$ If the fine-grained gneiss and schist of the intervening plate are of Mesozoic protolithic age, as interpreted by Ballard (1990), the lower contact of this plate with the underlying overturned Paleozoic rocks must be a major fault. By contrast, if these rocks are of Proterozoic age, a possibility offered in this report, a major fault is not required. Additional work is needed to resolve the age of the rocks and the nature of their lower contact. In this report, for simplicity, the contact is not shown as a fault, although the work of Ballard (1990) suggests that at least some Late Cretaceous fault movement probably took place along parts of the contact.
} 
Much less intense Late Cretaceous deformation and metamorphism affected the McCoy Mountains Formation and the underlying Jurassic volcanic rocks in the McCoy Mountains. The main signs of deformation in these rocks are a penetrative north-dipping cleavage, along with local folding in the McCoy Mountains Formation, some of which is south-vergent (Pelka, 1973; Hamilton, 1987; Stone and Pelka, 1989). The cleavage is approximately parallel to the more intense deformational fabric in the Little Maria Mountains to the north and could have formed in the lower plate of the same thrust system exposed in that range, as illustrated in figure 3. Deformation of the McCoy Mountains Formation predated emplacement of plutonic rocks about $73 \mathrm{Ma}$ in the Coxcomb Mountains $30 \mathrm{~km}$ west of the map area (Barth and others, 2004), and thus was approximately coeval with deformation in the Big Maria and Little Maria Mountains.

In the Mule Mountains, Late Cretaceous deformation is represented by the Mule Mountains thrust that emplaced Jurassic plutonic rocks, Triassic plutonic rocks, and Proterozoic gneiss north-northeastward over Jurassic volcanic rocks (Tosdal, 1988, 1990). The Mule Mountains thrust is a ductile shear zone along which deformation took place under lower greenschist facies metamorphic conditions between 79 and 70 Ma (Tosdal, 1990). To the north, a thrust fault exposed at the south end of the McCoy Mountains is interpreted as the floor thrust of the Mule Mountains thrust system (Tosdal, 1990). This thrust places rocks questionably identified as Jurassic volcanic rocks and member A of the McCoy Mountains Formation above the stratigraphically highest member L of the McCoy Mountains Formation. Regional structural relations suggest that north-vergent deformation in the Mule Mountains thrust system postdated south-vergent deformation of the McCoy Mountains Formation (Tosdal, 1990; Ballard, 1990). From the exposures in the Mule and McCoy Mountains, the Mule Mountains thrust system is inferred to extend beyond the map area (fig. 1) at least $50 \mathrm{~km}$ westward to the Coxcomb Mountains and at least $30 \mathrm{~km}$ eastward to the Dome Rock Mountains (Tosdal, 1990).

\section{Tertiary Rocks and Faults}

Tertiary rocks primarily of Miocene age are largely restricted to the northern part of the map area. The most extensive outcrops are in the Riverside Mountains where a thick, south-dipping sequence of fanglomerate, sedimentary breccia, and slide blocks (Tfbx) rests on Proterozoic gneiss and granite (Hamilton, 1982, 1984). Minor volcanic rocks (Tv) are interbedded with the sedimentary deposits. The sequence clearly was deposited in an area of high local topographic relief, and the basal contact of the sequence reflects deep pre-Miocene erosion. Other significant exposures of sedimentary breccia (Tbx) and slide blocks (Tsb) form low hills north of the Little Maria Mountains and a group of aligned hills between the Big Maria and Little Maria Mountains. Scattered outcrops of Tertiary volcanic rocks are present in the Mule Mountains (Tosdal, 1988), and a few felsic plugs (Ti) are present in the northern Big Maria Mountains (Hamilton, 1984).

Hamilton $(1982,1984)$ showed that the Tertiary rocks and their Proterozoic basement in the Riverside Mountains form the upper plate of a Miocene low-angle normal (detachment) fault structurally similar to the Whipple Mountains detachment fault $40 \mathrm{~km}$ to the north. A similar (possibly the same) fault is exposed beneath brecciated and altered Proterozoic gneiss along the north flank of the Big Maria Mountains and is inferred to underlie the similar gneiss of Quien Sabe Point in the northeastern corner of this range (fig. 1). These faults excise as much as $10 \mathrm{~km}$ of crustal section and are inferred to represent many kilometers of relative northeastward transport of the upper plate (Hamilton, 1982). The detachment fault in the northern Big Maria Mountains marks part of the west margin of the Colorado River extensional corridor of Howard and John (1987), a region of metamorphic core complexes and detachment faults that represent an estimated $50 \mathrm{~km}$ of northeastward upper-plate slip. In keeping with the regional interpretation of Howard and John (1987, fig. 2), the covered trace of this fault may extend west to separate pre-Tertiary bedrock of the Little Maria Mountains from the sedimentary breccia deposits to the north (fig. 1). Faulting in the extensional corridor took place between about 22 and $15 \mathrm{Ma}$ (Howard and John, 1987).

Other faults of known or presumed Tertiary age are exposed in most of the mountainous parts of the map area. In the Big Maria Mountains, a prominent northwest-trending strike-slip fault with about $1.5 \mathrm{~km}$ 
of dextral slip and an arcuate, east-dipping fault with about $1.5 \mathrm{~km}$ of normal displacement have been mapped and described by Hamilton $(1982,1984)$. These faults are interpreted to record post-detachment fault extension (Hamilton, 1982). Two prominent northwest-striking faults in the northern Little Maria Mountains were shown as right-lateral strike-slip faults by Emerson (1982) but also could be dip-slip faults with the east side down. Several faults offset strata of the McCoy Mountains Formation in the McCoy Mountains; some of these are clearly normal faults, and three of the faults have Tertiary sedimentary breccia deposits in their hanging walls (Stone and Pelka, 1989).

In addition to these exposed faults, gravity anomalies (Rotstein and others, 1976; Mariano and others, 1986) suggest the presence of several subsurface faults of presumed Tertiary age in the southern part of the map area. On the basis of the gravity anomalies, northwest-trending faults are inferred beneath Quaternary alluvium on both sides of the McCoy Mountains, along McCoy Wash, and on the southwest sides of the Big Maria and Little Maria Mountains; northeast-trending faults are inferred on the west side of the Mule Mountains and beneath Chuckwalla Valley (fig. 1). The gravity anomalies reflect abrupt changes in basement elevation strongly suggestive of dip-slip fault movements (Rotstein and others, 1976). In addition, some of the faults may have undergone right-lateral strike-slip movement as interpreted by Richard (1993). The aligned hills of sedimentary breccia (Tbx; Tu in fig. 1) between the Big Maria and Little Maria Mountains do not appear to coincide with a major gravity anomaly or subsurface fault zone, but this breccia may have been deposited in a shallow structural depression that branched northwestward from the inferred major fault zone on the southwest side of the Big Maria Mountains.

\section{Latest Tertiary and Quaternary Surficial Deposits}

Surficial deposits of late Miocene to Holocene age form most of the land surface in the west half of the Blythe 30' by 60' quadrangle. Most of these deposits are composed of alluvium either derived from local mountain ranges or transported into the area by the Colorado River.

The oldest surficial deposits in the map area are locally derived gravels of probable late Miocene age $\left(\mathrm{Ta}_{1}\right)$. These gravels are overlain by limestone and fine-grained clastic deposits assigned to the late Miocene and (or) Pliocene Bouse Formation (Tbl, Tbs). Foraminifera, mollusks, and ostracodes from Bouse sediments suggest a marine to brackish-water environment (Smith, 1970), and most workers have interpreted the Bouse Formation to represent deposition in an estuary or marine embayment connected to the proto-Gulf of California (Metzger and others, 1973; Buising, 1990). Alternatively, Spencer and Patchett (1997) have shown that strontium isotope data from the Bouse Formation indicate a lacustrine rather than a marine or estuarine environment, and they have suggested that the Bouse fauna was introduced to the lacustrine environment through transport by birds. The depositional setting of the Bouse Formation remains debatable (Spencer and Pearthree, 2001; Patchett and Spencer, 2001; Lucchitta and others, 2001). Regionally, the Bouse Formation is gradationally overlain by fluvial deposits of the ancestral Colorado River (Buising, 1990), although this relation is not exposed in the map area.

Most of the locally derived alluvial-fan and alluvial-valley deposits in the map area are divided into five units $\left(\mathrm{QTa} \mathrm{a}_{2}, \mathrm{Qa}_{3}-\mathrm{Qa}_{6}\right)$ based primarily on their surface morphology and their appearance on aerial photographs. Each of these units corresponds to one or more of nine regionally widespread alluvial geomorphic surfaces distinguished by Bull (1991). The oldest and thickest unit $\left(\mathrm{QTa}_{2}\right.$, equivalent to Q1 of Bull) forms deeply dissected hills and ridges adjacent to the range fronts. Parts of this unit could be as old as late Miocene and equivalent to $T a_{1}$. Alluvium of primarily middle and late Pleistocene age $\left(\mathrm{Qa}_{3}\right.$ and $\mathrm{Qa}_{4}$, mostly equivalent to the Q2 surfaces of Bull) forms smooth, varnished pavements, whereas Holocene alluvium $\left(\mathrm{Qa}_{5}\right.$ and $\mathrm{Qa}_{6}$, mostly equivalent to the $\mathrm{Q} 3$ and $\mathrm{Q} 4 \mathrm{a}$ surfaces of Bull) forms rough surfaces that preserve relict depositional bars and channels. Most of the middle Pleistocene to Holocene alluvial units are interpreted as the products of aggradation events that took place during interglacial climatic environments (Bull, 1991). The youngest locally derived alluvium is that of modern washes ( $Q w$, equivalent to $Q 4 b$ of Bull), which commonly are incised many meters into the older alluvial-fan deposits. 
Several units composed largely or entirely of alluvium deposited by the Colorado River have been distinguished in the map area. These units are characterized by the presence of light-colored, locally crossbedded sand and rounded gravel of resistant rock types exotic to the area. Most of these deposits (Qpv, Qbm, QTe) are concentrated along the margins of the modern Colorado River flood plain, where they apparently interfinger with locally derived alluvium. One unit (QTmw), however, crops out high on Palo Verde Mesa as much as $8 \mathrm{~km}$ from the flood plain, and another (QTmm) surrounds the northeastern part of the Mule Mountains. These high-standing units represent one or more major aggradational events when the ancestral Colorado River flowed across the area at much higher elevations than the modern river. Metzger and others (1973) recognized two major pre-Holocene aggradations, one of probable Pliocene-Pleistocene age and the other probably middle to late Pleistocene, each of which was followed by a period of degradation. The last degradation was followed by Holocene aggradation that has deposited the sediments of the modern flood plain (Qr) (Metzger and others, 1973).

Much of Rice Valley near the north edge of the map area is covered by eolian sand. This large sand field is characterized by abundant, partially stabilized linear dunes with an average orientation of eastsoutheast. These dunes are conspicuous on aerial photographs and have been accurately mapped, although they have not been studied in detail. The Rice Valley sand field is at the end of a prominent pathway of southeastward sand transport that begins near Bristol Dry Lake $100 \mathrm{~km}$ to the northwest (Zimbelman and Williams, 2002). To the south, smaller areas of eolian sand in Chuckwalla Valley are at the southeast end of another sand pathway that begins near Dale Dry Lake, also about $100 \mathrm{~km}$ to the northwest.

The only other surficial deposits in the area are playa sediments that cover the floor of Ford Dry Lake and another small dry lake in Chuckwalla Valley. A brief visit to Ford Dry Lake showed that these deposits consist largely or entirely of fine-grained clastic sediments and apparently lack evaporites.

\section{Quaternary Faults}

There is little evidence of Quaternary faulting in the map area. The only faults known to cut Quaternary deposits in the area are those that form the northwest-trending Blythe Graben on the southwest side of the Big Maria Mountains (Fugro, Inc., 1975). As described by Purcell and Miller (1980), this graben is about $5.5 \mathrm{~km}$ long, $92 \mathrm{~m}$ wide, and has about $3 \mathrm{~m}$ of vertical relief. The graben cuts alluvial-fan deposits dated as 6 to $31 \mathrm{ka}$ (Purcell and Miller, 1980) and shown as $\mathrm{Qa}_{3}$ on the map presented here; it appears to be overlapped by younger sediments mapped here as $\mathrm{Qa}_{5}$. The tectonic significance of the Blythe Graben is unknown, although it does approximately coincide with a geophysically delineated subsurface fault (fig. 1). The graben was not examined during the present study.

\section{DESCRIPTION OF MAP UNITS}

Qw Alluvium of modern washes (Holocene) - Unconsolidated, angular to subangular gravel and sand derived from local mountain ranges. Boulder- and cobble-rich wash deposits proximal to mountain fronts grade downstream into pebbly and sandy distal deposits. Mapped areas include both large individual washes and closely spaced smaller washes. Wash deposits commonly grade laterally and downstream into young alluvial sand and gravel of $\mathrm{Qa}_{6}$. Equivalent to deposits forming geomorphic surface Q4b of Bull (1991)

Qr Alluvium of the modern Colorado River flood plain (Holocene) - Unconsolidated clay, silt, and sand. Mostly covered with thick vegetation or converted to farm land

Qp Playa lake deposits (Holocene) - Unconsolidated clay, silt, and sand. Vegetative cover sparse. Locally includes thin veneer of eolian sand

Qs Eolian sand (Holocene) - Unconsolidated sand dunes and sheets. Dunes are partially stabilized by vegetation. Brown lines mark dune crests mapped from aerial photographs 
Alluvial-fan and alluvial-valley deposits (Holocene to Miocene) - Angular to subangular gravel and sand derived from local mountain ranges. Mostly unconsolidated to weakly consolidated; oldest deposits are locally well consolidated. Divided into six units distinguished by contrasting surficial and geomorphic characteristics:

$\mathrm{Qa}_{6} \quad$ Unit 6 (Holocene)-Young alluvial-fan and alluvial-valley deposits characterized by a lack of desert varnish, generally fine grain size, and evidence of recent sediment transport. Consists mostly of sand, pebbly sand, and sandy pebble-gravel; forms very gently sloping to nearly flat valley floors marginal to older, varnished alluvial-fan deposits. Surfaces are covered by sparse to moderately dense vegetation and commonly are transected by shallow channels of active sediment transport. Thin accumulations of eolian sand, not mapped separately, are present locally. Near mountains, unit includes relatively coarse, youthful, unvarnished gravel deposits of alluvial fans that grade downslope into the fine-grained deposits; some of these gravels form surfaces that may be inactive and equivalent to some deposits mapped elsewhere as $\mathrm{Qa}_{5}$. Unit also includes deposits of many minor washes and channels (equivalent to $\mathrm{Qw}$ ) too small to be mapped separately. Probably equivalent primarily to deposits forming geomorphic surface Q4a of Bull (1991), which is interpreted to range in age from 0.1 to $2 \mathrm{ka}$

$\mathrm{Qa}_{5} \quad$ Unit 5 (Holocene) - Alluvial-fan deposits of gravel and sand that form relatively young, undissected to little-dissected, unvarnished to lightly varnished surfaces typically displaying bars and swales modified from original depositional bars and channels. Bars are composed of poorly sorted gravel commonly as coarse as $20 \mathrm{~cm}$ in diameter; swales are composed of sand and fine gravel typically $2 \mathrm{~cm}$ in diameter or smaller. Vegetation can be moderately dense in swales but is sparse on bars. Surfaces generally appear to be depositionally inactive, but some surfaces may have been modified by recent stream flow and sedimentation and thus may be correlative with some surfaces of unit $6\left(\mathrm{Qa}_{6}\right)$. Probably equivalent primarily to deposits forming geomorphic surfaces Q3c and Q3b of Bull (1991), which are interpreted to range in age from 2 to $8 \mathrm{ka}$

$\mathrm{Qa}_{4} \quad$ Unit 4 (Holocene and Pleistocene) - Relatively old, dissected, pavement-forming alluvial-fan deposits of gravel and sand that are similar to the much more extensive unit $3\left(\mathrm{Qa}_{3}\right)$ but are composed primarily of light-colored, unvarnished granitic rock fragments and thus form surfaces much lighter in color than the varnished pavements typical of $\mathrm{Qa}_{3}$. Covers small areas flanking northwestern Little Maria and southeastern Big Maria Mountains

$\mathrm{Qa}_{3} \quad$ Unit 3 (Holocene and Pleistocene) - Alluvial-fan deposits of gravel and sand that form relatively old, dissected surfaces mostly characterized by smooth, varnished desert pavement. Typical pavements have little or no surface relief and are composed of tightly to moderately packed, angular to subangular rock fragments averaging 2 to $10 \mathrm{~cm}$ across and generally less than 30 percent interstitial sand. Most surfaces have a dark brown to nearly black desert varnish, but some surfaces are lighter in color owing either to a relative abundance of unvarnished or lightly varnished granitic gravel or to vehicular or other human disturbances that have disrupted and crushed the original pavement. Pavement surfaces are dissected and drained by dendritic networks of sandy channels that vary in depth from less than $1 \mathrm{~m}$ to several meters; vegetation is typically dense in these channels but is sparse to absent on the pavement surfaces. Unit includes surfaces that range from only slightly dissected to deeply dissected, and that probably represent a wide range in age. Unit also includes some bar-andswale surfaces similar morphologically to those of unit $5\left(\mathrm{Qa}_{5}\right)$ but most of which are moderately to darkly varnished, probably older than most surfaces of that unit, and difficult to distinguish on aerial photographs from the smoother desert pavements. Probably equivalent primarily to deposits forming geomorphic surfaces Q3a to Q2a of Bull (1991), which are interpreted to range in age from 8 to $730 \mathrm{ka}$ 
$\mathrm{QTa}_{2} \quad$ Unit 2 (Pleistocene to Miocene) - Alluvial-fan deposits of fine to coarse, poorly sorted gravel and sand that typically form high, deeply dissected, narrow ridges extending away from mountain fronts. Some ridge crests are relatively flat, narrow plateaus that preserve small tracts of smooth desert pavement like that of $\mathrm{Qa}_{3}$, but most ridge crests are sharp to rounded and presumably have been eroded to a level below that of any preexisting alluvial surface. The youngest deposits assigned to this unit may overlap in age with the oldest deposits assigned to unit $3\left(\mathrm{Qa}_{3}\right)$; the oldest deposits assigned to this unit may be coeval with $\mathrm{Ta}_{1}$. In two places, alluvium assigned to this unit depositionally overlies limestone or tufa of the Bouse Formation (Tbl). Probably largely equivalent to deposits forming geomorphic surface Q1 of Bull (1991), which is interpreted to be older than 1.2 Ma

$\mathrm{Ta}_{1} \quad$ Unit 1 (Miocene) - Alluvial-fan deposits of gravel and sand that demonstrably underlie limestone or tufa of the Bouse Formation (Tbl); recognized only in a few places on the east sides of the Riverside and Big Maria Mountains. Best exposed in bare washes east of the Riverside Mountains where unit consists of well consolidated, reddish-brown, sandy conglomerate containing abundant clasts of gneiss and schist. Away from these wash exposures, unit forms hills and ridges of poorly sorted gravel similar to those of QTa $\mathrm{T}_{2}$. Observed contacts with overlying limestone (Tbl) are concordant. Equivalent to the fanglomerate of Metzger and others (1973) and the fanglomerate of Osborne Wash of Carr and Dickey (1980)

Alluvial deposits of the ancestral Colorado River (Pleistocene and Pliocene)-Unconsolidated to well consolidated alluvial deposits of moderately to well sorted clay, silt, sand, and gravel derived from distant sources and deposited by the ancestral Colorado River; exposed primarily along bluffs and mesas bordering the modern Colorado River flood plain. Clay, silt, and sand deposits are light in color, commonly well laminated, and typically friable; gravels and conglomerates consist of rounded pebbles and cobbles of resistant lithology, primarily quartzite and other siliceous rock types. As mapped, some units also include locally derived alluvial-fan deposits. Divided into the following units:

Qpv Alluvial deposits of Palo Verde Mesa (Pleistocene) - Unconsolidated to weakly consolidated deposits of sand, pebbly sand, silt, and clay that are locally well exposed along the scarp of Palo Verde Mesa, which bounds the flood plain of the Colorado River. Scarp exposures, typically about 20 to $30 \mathrm{~m}$ thick, show an upper, slope-forming unit of tan to light-gray, sandy and pebbly alluvium and a lower, cliff-forming unit of light-reddish-brown, interbedded finegrained sand, silt, and clay. The upper unit extends westward from the top of the scarp to form the surface of Palo Verde Mesa, which is composed of unconsolidated sand and pebbly sand containing a mixture of local and river pebbles generally less than $4 \mathrm{~cm}$ in diameter. South of McCoy Wash, a prominent terrace is developed in Qpv at a height of about 20 to 25 $\mathrm{m}$ above the flood plain and about $20 \mathrm{~m}$ below the upper surface of Palo Verde Mesa. The subtle contact between units $\mathrm{Qpv}$ and $\mathrm{Qa}_{6}$ is placed at the western limit of river pebbles present at the surface of Palo Verde Mesa; this contact approximately coincides with the slight break in slope that marks the distal margins of alluvial fans and valleys extending from the mountains to the west. Northeasternmost exposures of Qpv apparently are overlain by alluvial-fan deposits assigned to unit $\mathrm{Qa}_{5}$ and may interfinger with alluvial-fan deposits assigned to unit $\mathrm{Qa}_{3}$. Deposits herein assigned to $\mathrm{Qpv}$ represent units D and E of Metzger and others (1973, p. G24-G25), which are interpreted to be of probable middle to late Pleistocene age

Qbm Alluvial deposits east of the Big Maria Mountains (Pleistocene) - Sand and gravel deposits containing a mixture of rounded river gravel and angular to subangular, locally derived gravel. 
Sand is tan to light reddish brown and locally is associated with minor silt and clay; river gravel is mostly $4 \mathrm{~cm}$ or less in diameter and varnished to various shades of brown. Unit typically forms dissected hills with light- to medium-brown surfaces distinct from the generally more darkly varnished surfaces of alluvial-fan unit $\mathrm{Qa}_{3}$. West of Hall Island, unit forms at least four distinct terraces ranging from about 10 to $40 \mathrm{~m}$ in height above the Colorado River flood plain. Unit is undated but probably is middle to late Pleistocene based on observed relations of subunits (described below) with unit $\mathrm{Qa}_{3}$. In part equivalent to river gravel of Hamilton (1964). Includes the following subunits:

Qbmg Gravel-dominated deposits-Deposits composed almost entirely of rounded river pebbles and cobbles due west of Hall Island. Forms an elevated ridge representing the upper 1 to $2 \mathrm{~m}$ of the local alluvial sequence; overlies Pleistocene, pavement-forming alluvial-fan deposits assigned to unit $\mathrm{Qa}_{3}$

Qbms Sand-dominated deposits-Unconsolidated to weakly consolidated, tan to light-reddishbrown sand and pebbly sand forming several small hills southwest of Hall Island. Gravel in these sandy deposits is largely of local origin but includes about 10 percent rounded river pebbles. In at least one place, sandy deposits overlie alluvial-fan gravel deposits of $\mathrm{Qa}_{3}$

QTmm Alluvial deposits of the Mule Mountains (Pleistocene or Pliocene) —Weakly to moderately consolidated sand and pebbly sand deposits, interbedded with locally derived gravel deposits. Sand and pebbly sand deposits are light gray, tan, and light reddish brown, fine to coarse grained, well to moderately well sorted, generally thin bedded where well exposed, and locally cross bedded. Cross beds measured at two localities dip about $25^{\circ}$ southwest to southeast, suggesting generally southward sediment transport. Rounded river pebbles, mostly quartzite and chert, are locally associated with the sandy deposits. The thin-bedded and crossbedded sands of this unit are similar to those of unit QTe (alluvial deposits of the Ehrenberg area) and are tentatively interpreted as coeval with that unit. Unit forms deeply dissected hills and ridges capped by coarse cobble to boulder gravels of local derivation that may be equivalent to unit $\mathrm{QTa} \mathrm{T}_{2}$; these gravels are mapped as part of QTmm and form much of the surface area included in the unit. Unit is exposed at elevations ranging from about 150 to $240 \mathrm{~m}$ and extends through a broad depression in the Mule Mountains; this depression may mark a former course of the ancestral Colorado River

QTmw Alluvial deposits of the McCoy Wash area (Pleistocene and/or Pliocene) —Deposits of rounded river gravel and minor locally derived gravel that form several broad hills standing 15 to $25 \mathrm{~m}$ above Palo Verde Mesa in the vicinity of McCoy Wash and the southeast side of the McCoy Mountains. River gravel averages 2 to $4 \mathrm{~cm}$ and is as large as $15 \mathrm{~cm}$ in diameter; most is varnished. Rare hillside exposures show that the surface gravels are underlain by brown, well consolidated calcareous or gypsiferous sandstone. Stratigraphic relations of QTmw with adjacent deposits of Palo Verde Mesa (Qpv) are unclear. Metzger and others (1973, p. G22) considered deposits here mapped as QTmw as part of their unit B of presumed Pleistocene and Pliocene age

QTe Alluvial deposits of the Ehrenberg area (Pleistocene and/or Pliocene)-Heterogeneous deposits of sand and gravel forming dissected bluffs and mesas that bound the east side of the Colorado River flood plain near the southeast corner of the map area. Well exposed in cliff faces along edge of flood plain and on sides of tributary washes. Unit consists largely of weakly to moderately consolidated, light-gray to brownish-gray, fine- to coarse-grained sandstone that commonly exhibits well developed horizontal and cross stratification. Some sandstone weathers into thin plates defined by horizontal stratification. Much of the sandstone is cemented by calcite. The sandstone commonly contains scattered pebbles and 
conglomeratic lenses composed of both rounded river gravel and angular gravel of local derivation. Conglomeratic sequences several meters thick are present locally. A well exposed section in a cliff face along the edge of the flood plain $10 \mathrm{~km}$ south of Ehrenberg consists of about $8 \mathrm{~m}$ of gray, partly crossbedded sandstone overlain by 15 to $20 \mathrm{~m}$ of conglomerate predominantly composed of river gravel as much as $25 \mathrm{~cm}$ in diameter. These Colorado River sand and gravel deposits are capped by locally derived gravel deposits that form the surface of most of the area included in the unit. Age unknown; considered part of unit B of Pleistocene and Pliocene age by Metzger and others (1973). Includes the following subunit:

QTes Sand-dominated deposits - Unconsolidated to very weakly consolidated deposits composed mainly of tan sand and pebbly sand; these deposits form two large areas near Ehrenberg. Both river and locally derived gravel is present; rounded river gravel is mostly less than $4 \mathrm{~cm}$ in diameter and angular local gravel commonly is as much as $10 \mathrm{~cm}$ across. Patch south of Ehrenberg overlies QTe; patch northeast of Ehrenberg underlies locally derived gravel deposits assigned to QTe

Bouse Formation (Pliocene and/or Miocene) - Fine-grained clastic sedimentary rocks and limestone commonly interpreted to have been deposited in an marine embayment of the Gulf of California (Metzger, 1968; Metzger and others, 1973; Buising, 1990), but interpreted as lake deposits by Spencer and Patchett (1997). Regionally, unit may range in age from late Miocene to Pliocene (Buising, 1990); exposures $40 \mathrm{~km}$ south of map area contain a tuff considered to be about 5.0 Ma based on ${ }^{40} \mathrm{Ar} /{ }^{39} \mathrm{Ar}$ geochronologic data (Spencer and others, 2001). Consists of the following units:

Tbs Fine-grained clastic sedimentary rocks - Pink to green, unlithified, horizontally bedded mud, silt, and sand shown in two small areas on southeast side of Riverside Mountains and one small area on east side of Big Maria Mountains. Overlies fanglomerate $\left(\mathrm{Ta}_{1}\right)$ composed predominantly of angular schist and gneiss pebbles; overlain by locally derived gravel deposits assigned to QTa 2 . Maximum exposed thickness about 10 to $15 \mathrm{~m}$. Mapped as unnamed lake deposits by Hamilton (1964) and as Bouse Formation by Metzger and others (1973). Locally contains foraminifera and ostracodes (Hamilton, 1960; Smith, 1970; Warren Hamilton, written commun., 2004, citing paleontological reports prepared by Patsy Smith and I.G. Sohn in 1958)

Tbl Limestone - Light-gray to light-brown, locally fossiliferous limestone found at numerous places along the eastern flanks of the Big Maria and Riverside Mountains. Occurs both as resistant tufa rinds on slopes and hillcrests and as bedded limestone that overlies very old alluvium $\left(\mathrm{Ta}_{1}\right)$. Tufa rinds generally are less than $0.5 \mathrm{~m}$ thick and cover areas ranging from a few square meters to several hundred square meters in size. Most rinds are formed on bedrock surfaces but some drape hills composed of very old alluvium $\left(\mathrm{Ta}_{1}\right)$. The tufa ranges from dense to porous and locally contains branching tubular structures typically 2 to $3 \mathrm{~mm}$ in diameter and $1 \mathrm{~cm}$ long. These structures, which may have been built by annelid worms (Buising, 1990), commonly form large patches in the upper few centimeters of the tufa. Bedded limestone overlying unit $\mathrm{Ta}_{1}$ is found in the canyon north of Black Point (southeastern Big Maria Mountains), where sandy to gravelly limestone beds form a sequence 15 to $20 \mathrm{~m}$ thick; some of this limestone is crossbedded. The gravel, as much as $5 \mathrm{~cm}$ in diameter, is angular and probably derived from local bedrock sources. Tufa with tubular structures is present locally at the base of the sequence. Fossils identified from the limestone at various localities in the map area include algae, ostracodes, barnacles, clams, and snails (Hamilton, 1960; Warren Hamilton, written commun., 2004, citing paleontological reports prepared by Richard Rezak and Wendell Woodring in 1958) 
Tbx Sedimentary breccia (Miocene and Oligocene?) - Unbedded, unsorted deposits of angular gravel and slide blocks, commonly monolitholigic. Interpreted as landslide deposits. Largest slide blocks are shown separately (Tsb)

Tsb Slide blocks (Miocene and Oligocene?) —Large, angular blocks and slabs of Mesozoic(?) and Paleozoic carbonate rocks and quartzite probably deposited by landslides. Generally brecciated

Tfbx Fanglomerate, sedimentary breccia, and slide blocks, undivided (Miocene and Oligocene?)Fanglomerate in association with sedimentary breccia and slide blocks like those mapped separately as units Tbx and Tsb, exposed in Riverside Mountains. Fanglomerate consists of distinctly to indistinctly bedded, poorly to well sorted conglomerate and sandstone containing angular to rounded clasts of local derivation. Includes basal red sandstone unit 100 to $150 \mathrm{~m}$ thick. Total thickness of unit more than $1 \mathrm{~km}$ (Hamilton, 1964)

$\mathrm{Ti} \quad$ Felsic intrusive rocks (Miocene and Oligocene?) - Light-colored, fine-grained, hypabyssal intrusive rocks of rhyolitic to dacitic composition. In Big Maria Mountains, includes dacite that has a hornblende potassium-argon age of about $22 \mathrm{Ma}$ (Martin and others, 1982)

Tv Volcanic rocks (Miocene and Oligocene?) — Rhyolitic to basaltic volcanic rocks including lava flows, flow breccia, airfall tuff, and ashfall tuff. Exposed in small outcrops in Mule and Riverside Mountains. In Riverside Mountains, includes andesite that has a whole-rock potassium-argon age of about 23.5 Ma (Martin and others, 1982)

Kgp Gneissic porphyritic granite (Cretaceous) - Distinctly to indistinctly foliated and lineated, medium- to coarse-grained biotite granite to granodiorite containing phenocrysts of potassium feldspar 1 to $5 \mathrm{~cm}$ long. Exposed in northwestern Little Maria Mountains. Considered part of the Late Cretaceous Cadiz Valley batholith (K.A. Howard, oral commun., 1990), parts of which intrude rocks as young as the McCoy Mountains Formation in the Coxcomb Mountains $30 \mathrm{~km}$ west of the map area. A biotite potassium-argon age of about $55 \mathrm{Ma}$ indicates the minimum age of crystallization (Martin and others, 1982)

KJa Andesite (Cretaceous or Jurassic) - Highly foliated, fine-grained, dark-green to black andesite interpreted as sills intrusive into member A(?) of the McCoy Mountains Formation (KJma?) at the south end of the McCoy Mountains. Possibly correlative with diorite that intrudes units as young as member F of the McCoy Mountains Formation in the Dome Rock Mountains 15 $\mathrm{km}$ east of the map area (Tosdal, 1988; Stone, 1990)

McCoy Mountains Formation (Cretaceous and Jurassic?) - Primarily sandstone and conglomerate; minor shale, mudstone, and siltstone. In map area, exposed only in McCoy Mountains. Largely or entirely of fluvial origin (Harding and Coney, 1985). Weakly metamorphosed; beds commonly exhibit crosscutting foliation or cleavage. Age bracketed by underlying Late Jurassic volcanic rocks (Jv) and by Late Cretaceous ( $\sim 73 \mathrm{Ma}$ ) plutonic rocks that intrude formation in Coxcomb Mountains $30 \mathrm{~km}$ west of map area (Barth and others, 2004). Detrital-zircon uranium-lead age determinations in map area indicate that members $C$ through L were deposited after $116 \mathrm{Ma}$ (Barth and others, 2004); members A and B could be as old as Late Jurassic (Fackler-Adams and others, 1997). In Dome Rock Mountains to the east, upper part of the formation contains a tuff having a uranium-lead zircon age of about 79 Ma (Tosdal and Stone, 1994). Formation in map area is about $8 \mathrm{~km}$ thick. Divided into the following informal members:

Kml Member L (Cretaceous) - Light-gray arkosic sandstone, conglomerate, and minor shale, all micaceous and phyllitic. Conglomerate clasts are quartzite, volcanic rocks, and granitic rocks. 
Base and top faulted; exposed thickness about $300 \mathrm{~m}$. Contains detrital zircons as young as $84 \mathrm{Ma}$ (Barth and others, 2004)

Kmk Member K (Cretaceous) - Dark-gray, fine-grained arkosic to volcanic-lithic sandstone, lightgray phyllitic shale, and minor conglomerate containing clasts of volcanic and granitic rocks. Exposed thickness about $300 \mathrm{~m}$

Kmj Member J (Cretaceous) - Dark-gray, medium- to coarse-grained arkosic to volcanic-lithic sandstone and conglomerate; lowermost part contains minor light-gray arkosic sandstone. Coarsens upward; uppermost $100 \mathrm{~m}$ consists of massive conglomerate. Conglomerate clasts are granitic and volcanic rocks. Thickness about $350 \mathrm{~m}$

Kmi Member I (Cretaceous) - Light-gray, medium- to coarse-grained arkosic and micaceous sandstone, conglomeratic sandstone, and conglomerate. Massive ledges of conglomerate are present at base. Conglomerate clasts are quartzite, carbonate rocks, and granitic rocks. Thickness about $300 \mathrm{~m}$

Kmh Member H (Cretaceous) - Light-gray, fine-grained arkosic sandstone, conglomeratic sandstone, and shale, all micaceous and phyllitic. Thickness about 50 to $250 \mathrm{~m}$. Contains detrital zircons as young as $87 \mathrm{Ma}$ (Barth and others, 2004)

Kmg Member G (Cretaceous) - Upper part consists of dark-greenish-gray, fine-grained arkosic to volcanic-lithic sandstone; lower part consists of light-gray to tan phyllitic and calcareous shale, tan calcareous sandstone, and conglomerate containing clasts of quartzite and carbonate rocks. Lower contact truncates beds in member $\mathrm{F}$ (unit $\mathrm{Kmf}$ ) at a low angle and is interpreted as an intraformational unconformity. Thickness about 200 to $600 \mathrm{~m}$. Locally contains fragments of late Early Cretaceous or younger fossil wood (Pelka, 1973; Stone and others, 1987). Contains detrital zircons as young as $93 \mathrm{Ma}$ (Barth and others, 2004)

Kmf Member F (Cretaceous) - Light- to medium-gray, fine- to coarse-grained arkosic sandstone and conglomerate interbedded with less abundant light-gray phyllitic shale. Dark-gray to dark-greenish-gray, very fine grained to fine-grained volcanic-lithic sandstone and siltstone present in upper part. Conglomerate clasts are granitic rocks, quartzite, volcanic rocks, and minor carbonate rocks. Grades upward from conglomerate and sandstone in lower part to very fine grained sandstone and siltstone in upper part. Thickness about 2,600 m. Equivalent strata in Palen Mountains $3 \mathrm{~km}$ west of map area contain fragments of late Early Cretaceous or younger fossil wood (Pelka, 1973; Stone and others, 1987). Uppermost part of member contains detrital zircons as young as $91 \mathrm{Ma}$ (Barth and others, 2004)

Kme Member E (Cretaceous) - Light-gray phyllitic shale; light-gray, dark-gray, and greenish-gray arkosic and volcanic-lithic sandstone; and minor conglomerate and calcareous rocks. Conglomerate clasts are quartzite, volcanic rocks, and granitic rocks. Grayish-orange, calcareous shale present near top. Thickness about 1,500 $\mathrm{m}$. Contains detrital zircons as young as $165 \mathrm{Ma}$ (Barth and others, 2004)

Kmd Member D (Cretaceous) - Dark-maroon phyllitic shale and silty to sandy shale interbedded with minor volcanic-lithic sandstone and conglomerate containing clasts of quartzite and volcanic rocks. Locally intruded by foliated diorite (not mapped). Thickness about $300 \mathrm{~m}$

Kmc Member C (Cretaceous) - Dark-gray to dark-greenish-gray, very fine grained to fine-grained volcanic-lithic sandstone and siltstsone; dark-gray to dark-greenish-gray mudstone; and minor conglomerate. Mudstone commonly contains brown calcareous pods and lenses of unknown origin. Conglomerate clasts are quartzite and volcanic rocks. Thickness about 1,200 m. Contains detrital zircons as young as $109 \mathrm{Ma}$ (Barth and others, 2004) 
KJmb Member B (Cretaceous or Jurassic) - Maroon mudstone and siltstone, commonly containing brown calcareous pods and lenses of unknown origin. Interbedded with minor tan quartzite and brown, recystallized limestone. Thickness about $100 \mathrm{~m}$

KJma Member A (Cretaceous or Jurassic) - Tan, fine- to medium-grained quartzite and minor chert- and quartzite-clast conglomerate; interbedded with less abundant maroon mudstone and siltstone that commonly contain brown calcareous pods and lenses of unknown origin. Thickness about $350 \mathrm{~m}$. In Palen Mountains, equivalent strata are interpreted to interfinger with the underlying Late Jurassic volcanic rocks (Fackler-Adams and others, 1997); in Dome Rock Mountains, however, equivalent strata are disconformable on the underlying volcanic rocks, which were cut by faults prior to deposition of McCoy Mountains Formation (Tosdal and Stone, 1994). Youngest known detrital zircons are $179 \mathrm{Ma}$ (Barth and others, 2004). Queried outcrops at south end of McCoy Mountains consist of strongly foliated and folded phyllite and minor quartzite that overlie metamorphosed volcanic rocks (Jv?).

Jku Volcanic and sedimentary rocks, undivided (Jurassic and Triassic) - Mapped where units JV and $\mathrm{J}$ KS have not been distinguished owing to metamorphism and deformation

JV Volcanic rocks (Jurassic) - Mainly light-gray to light-greenish-gray, rhyodacitic volcanic and metavolcanic rocks composed of a microcrystalline, felsic groundmass and phenocrysts of plagioclase, quartz, potassium feldspar, and minor biotite averaging about $2 \mathrm{~mm}$ in diameter. Generally unbedded; commonly foliated and metamorphosed to greenschist and lower amphibolite facies. Interpreted to have originated as ash-flow tuff, flows, and hypabyssal porphyry (Tosdal, 1988; Tosdal and others, 1989; Fackler-Adams and others, 1997). In McCoy Mountains, upper $50 \mathrm{~m}$ includes volcanic sandstone, conglomerate composed of rhyodacite clasts, and highly altered, schistose metavolcanic rocks that may represent a metamorphosed paleosol. Considered part of the Middle to Late Jurassic Dome Rock sequence of Tosdal and others (1989). Sample near top of unit in McCoy Mountains has a uranium-lead zircon age of about $165 \mathrm{Ma}$ (Barth and others, 2004). Uranium-lead zircon ages from unit in Palen Mountains to the west range from about 175 to $155 \mathrm{Ma}$ (Fackler-Adams and others, 1997). In Riverside Mountains, includes greenstone of Hamilton (1964)

Jp Plutonic rocks (Jurassic) — Porphyritic granitoid rocks ranging in composition from granodiorite and quartz monzonite to quartz syenite, and equigranular rocks of varied composition including leucocratic granite, granodiorite, diorite, and gabbro. Commonly metamorphosed and foliated. Most abundant rock type is medium- to coarse-grained, strongly foliated to unfoliated, porphyritic granodiorite characterized by potassium feldspar phenocrysts 1 to $5 \mathrm{~cm}$ long and by clotted mafic minerals, primarily biotite. Leucocratic granite is fine to coarse grained and unfoliated to weakly foliated; it commonly intrudes the porphyritic granitoid rocks. Fine-grained, foliated granodiorite and diorite (Jpgd) are present locally. Considered part of the Middle to Late Jurassic Kitt Peak-Trigo Peaks superunit of Tosdal and others (1989). Uranium-lead zircon ages from rocks in map area are about $160 \mathrm{Ma}$ in Big Maria Mountains (L.T. Silver, oral commun. in Hamilton, 1982) and 165 Ma in Mule Mountains (Tosdal, 1988). Locally includes the following units:

Jpgd Foliated granodiorite and diorite

Jpgb Hornblende gabbro

JkS Sedimentary rocks (Jurassic and Triassic) — Variably metamorphosed sedimentary rocks generally consisting of, in ascending order: (1) greenschist, gypsiferous schist, and calcareous quartzite correlated with the Triassic Moenkopi Formation; (2) conglomeratic rocks containing clasts of quartzite, carbonate rocks, and granite; and (3) fine-grained, locally 
crossbedded quartzite (Hamilton, 1982; Ballard, 1990). The quartzite has been correlated with the Early Jurassic Aztec Sandstone (Hamilton, 1982, 1987) but more recently was interpreted as Middle Jurassic in age based on an interfingering relationship with the overlying volcanic rocks (equivalent to Jv) in the Palen Mountains to the west (FacklerAdams and others, 1997). Locally on west side of Big Maria Mountains, the quartzite unconformably overlies marble correlated with the Permian Kaibab Limestone (part of PPs)

kqm Quartz monzonite and monzodiorite (Triassic) - Porphyritic biotite quartz monzonite and hornblende monzodiorite exposed in Mule Mountains near south edge of map. Age is about $213 \mathrm{Ma}$ on the basis of uranium-lead analysis of zircon (Barth and others, 1990).

Lithologically similar to the Late Triassic Mount Lowe Granodiorite of the San Gabriel Mountains in southwestern California (Tosdal, 1988)

Kd Diorite and gabbro (Triassic?) — Hornblende diorite and gabbro, locally metamorphosed to amphibolite. Exposed near southwest corner of map. Age alternatively could be Proterozoic (Tosdal, 1988; R.E. Powell, written commun., 1989). In Little Chuckwalla Mountains, mixed with gneiss of probable Proterozoic age (R.M. Tosdal, written commun., 1990)

Pss Sedimentary rocks, undivided (Paleozoic) - Metamorphosed sedimentary rocks of presumed Paleozoic age consisting primarily of calcitic marble, dolomitic marble, calc-silicate rocks, quartzite, and schist. May include some rocks of Triassic and Jurassic age

PEs Sedimentary rocks (Permian to Cambrian) - Complete, or nearly complete, sequences of metamorphosed Permian to Cambrian strata equivalent to units PPs and M€s combined, but too thin to subdivide at map scale

PPs Sedimentary rocks (Permian and Pennsylvanian)-Metamorphosed sedimentary rocks consisting of, in ascending order: (1) massive, dark-brown-weathering calcareous quartzite and calc-silicate rocks correlated with the Permian and Pennsylvanian Supai Group; (2) quartzitic calc-silicate schist correlated with the Permian Hermit Formation; (3) fine-grained quartzite correlated with the Permian Coconino Sandstone; and (4) cherty and non-cherty calcitic and minor dolomitic marble correlated with the Permian Kaibab Limestone (Hamilton, 1982; Stone and others, 1983; Ballard, 1990). Thickness highly variable because of deformation

M€s Sedimentary rocks (Mississippian to Cambrian)-Metamorphosed sedimentary rocks consisting of, in ascending order: (1) feldspathic quartzite and conglomeratic quartzite correlated with the Cambrian Tapeats Sandstone; (2) schist and thin-bedded quartzite correlated with the Cambrian Bright Angel Shale; (3) massive dolomitic marble of probable Devonian and Cambrian age; and (4) massive calcitic marble correlated with the Mississippian Redwall Limestone (Hamilton, 1982; Stone and others, 1983; Ballard, 1990). Thickness highly variable because of deformation

Epg Porphyritic granite and augen gneiss (Proterozoic) - Coarse-grained granite and augen gneiss characterized by phenocrysts or porphyroblasts of potassium feldspar 1 to $5 \mathrm{~cm}$ long. In Big Maria Mountains, unit consists primarily of augen gneiss; in Riverside Mountains, unit consists of variably altered, mostly red, porphyritic granite in the upper plate of a Cenozoic detachment fault (Hamilton, 1982, 1984). Uranium-lead zircon age is about $1.4 \mathrm{Ga}$ based on two analyses from the southeastern Big Maria Mountains (L.T. Silver, oral commun. in Hamilton, 1982). Depositionally overlain by strata correlated with the Tapeats Sandstone (basal part of M€s)

Pgn Gneiss and amphibolite (Proterozoic) - In Riverside Mountains and northernmost Big Maria Mountains, including Quien Sabe Point, unit consists of varied gneissic and plutonic rocks 
known or inferred to overlie Cenozoic detachment faults (Hamilton, 1964, 1982, 1984). These rocks, which are varicolored, pervasively altered, and brecciated, include biotite gneiss, hornblende gneiss, aplitic granite, schist, and amphibolite. Below detachment fault in Big Maria Mountains, unit consists of dark, unaltered biotite and hornblende gneiss. Near Styx (a railroad siding in the northwestern part of the map area), unit consists of dark, phyllonitic gneiss interpreted to stratigraphically underlie overturned Paleozoic rocks (Ballard, 1990). Some of this gneiss lithologically resembles rocks assigned to unit MzPfg a short distance to the east

\section{UNITS OF MIXED OR UNCERTAIN AGE}

MzEgn Gneissic rocks, undivided (Mesozoic and Proterozoic) - Strongly foliated and lineated mylonitic gneiss, augen gneiss, and migmatitic gneiss. Probably includes rocks equivalent to those mapped elsewhere as Jp, Egn, and Ppg (Hamilton, 1982, 1984; Ballard, 1990)

MzEs Schist (Mesozoic or Proterozoic) — Quartz-rich, epidote-muscovite schist that structurally underlies overturned Paleozoic rocks and structurally overlies fine-grained gneiss ( $\mathrm{MzPfg})$ in northwestern Big Maria Mountains (Ballard, 1990). Interpreted as Jurassic and Triassic metasedimentary rocks by Hamilton (1984) and Ballard (1990). In this report, unit also is considered to be of possible Proterozoic age because definite evidence of Mesozoic age is lacking

MzPfg Fine-grained gneiss (Mesozoic or Proterozoic) — Fine-grained, dark-gray to grayish-green, strongly foliated and lineated quartzofeldspathic gneiss of uncertain age and origin (Ballard, 1990). Mapped as Jurassic and Triassic metasedimentary rocks (Jks) by Hamilton (1984); tentatively correlated with Jurassic plutonic rocks (Jp) by Ballard (1990). In this report, unit also is considered to be of possible Proterozoic age because of lithologic resemblance to gneiss of apparent Proterozoic age (Egn) near Styx

\section{REFERENCES CITED}

Anderson, J.L., 1983, Proterozoic anorogenic granitic plutonism of North America, in Medaris, L.G., Jr., Byers, C.W., Mickelson, D.M., and Shanks, W.C., eds., Proterozoic geology—selected papers from an international Proterozoic symposium: Geological Society of America Memoir 161, p. 133-154.

Ballard, S.N., 1990, The Mesozoic structural evolution of the Little Maria Mountains, Riverside County, California: Santa Barbara, University of California, Ph.D. dissertation, 380 p.

Barth, A.P., Tosdal, R.M., and Wooden, J.L., 1990, A petrologic comparison of Triassic plutonism in the San Gabriel and Mule Mountains, southern California: Journal of Geophysical Research, v. 95, no. B12, p. 20,075-20,096.

Barth, A.P., Tosdal, R.M., Wooden, J.L., and Howard, K.A., 1997, Triassic plutonism in southern California-southward younging of arc initiation along a truncated continental margin: Tectonics, $v$. 16, p. 290-304.

Barth, A.P., Wooden, J.L., Jacobson, C.E., and Probst, K., 2004, U-Pb geochronology and geochemistry of the McCoy Mountains Formation, southeastern California: A Cretaceous retroarc foreland basin: Geological Society of America Bulletin, v. 116, p. 142-153.

Buising, A.V., 1990, The Bouse Formation and bracketing units, southeastern California and western Arizona-implications for the evolution of the proto-Gulf of California and the lower Colorado River: Journal of Geophysical Research, v. 95, no. B12, p. 20,111-20,132.

Bull, W.B., 1991, Geomorphic responses to climatic change: New York, Oxford University Press, 326 p. 
Carr, W.J., and Dickey, D.D., 1980, Geologic map of the Vidal, California, and Parker SW, CaliforniaArizona quadrangles: U.S. Geological Survey Miscellaneous Investigations Series Map I-1125, scale $1: 24,000$.

Ellis, M.J., 1982, Structural analysis of the Big Maria Mountains, Riverside County, California, in Frost, E.G., and Martin, D.L., eds., Mesozoic-Cenozoic tectonic evolution of the Colorado River region, California, Arizona, and Nevada: San Diego, Calif., Cordilleran Publishers, p. 222-233.

Emerson, W.S., 1982, Geologic development and late Mesozoic deformation of the Little Maria Mountains, Riverside County, California, in Frost, E.G., and Martin, D.L., eds., Mesozoic-Cenozoic tectonic evolution of the Colorado River region, California, Arizona, and Nevada: San Diego, Calif., Cordilleran Publishers, p. 245-254.

Fackler-Adams, B.N., Busby, C.J., and Mattinson, J.M., 1997, Jurassic magmatism and sedimentation in the Palen Mountains, southeastern California-implications for regional tectonic controls on the Mesozoic continental arc: Geological Society of America Bulletin, v. 109, p. 1464-1484.

Fugro, Inc., 1975, Sundesert Nuclear Plant Units 1 \& 2 Early Site Review Report, v. 2, sec. 2.5-Geology and Seismology: San Diego Gas \& Electric Company, 161 p.

Hamilton, Warren, 1960, Pliocene(?) sediments of salt water origin near Blythe, southeastern California, in Geological Survey research 1960-short papers in the geological sciences: U.S. Geological Survey Professional Paper 400-B, p. B276-B277.

Hamilton, Warren, 1964, Geologic map of the Big Maria Mountains NE quadrangle, Riverside County, California and Yuma County, Arizona: U.S. Geological Survey Geologic Quadrangle Map GQ-350, scale $1: 24,000$.

Hamilton, Warren, 1982, Structural evolution of the Big Maria Mountains, northeastern Riverside County, southeastern California, in Frost, E.G., and Martin, D.L., eds., Mesozoic-Cenozoic tectonic evolution of the Colorado River region, California, Arizona, and Nevada: San Diego, Calif., Cordilleran Publishers, p. 1-27.

Hamilton, Warren, 1984, Generalized geologic map of the Big Maria Mountains region, northeastern Riverside County, southeastern California: U.S. Geological Survey Open-File Report 84-407, scale $1: 48,000,7 \mathrm{p}$.

Hamilton, Warren, 1987, Mesozoic geology and tectonics of the Big Maria Mountains region, southeastern California, in Dickinson, W.R., and Klute, M.A., eds., Mesozoic rocks of southern Arizona and adjacent areas: Arizona Geological Society Digest 18, p. 33-48.

Harding, L.E., and Coney, P.J., 1985, The geology of the McCoy Mountains Formation, southeastern California and southwestern Arizona: Geological Society of America Bulletin, v. 96, p. 755-769.

Hoisch, T.D., Miller, C.F., Heizler, M.T., Harrison, T.M., and Stoddard, E.F., 1988, Late Cretaceous regional metamorphism in southeastern California, in Ernst, W.G., ed., Metamorphism and crustal evolution of the western United States: Englewood Cliffs, N.J., Prentice Hall, p. 538-571.

Howard, K.A., 2002, Geologic map of the Sheep Hole Mountains 30' x 60' quadrangle, San Bernardino and Riverside Counties, California: U.S. Geological Survey Miscellaneous Field Studies Map MF-2344, scale $1: 100,000$.

Howard, K.A., and John, B.E., 1987, Crustal extension along a rooted system of imbricate low-angle faults-Colorado River extensional corridor, California and Arizona, in Coward, M.P., Dewey, J.F., and Hancock, P.L., eds., Continental extensional tectonics: Geological Society Special Publication 28, p. 299-311. 
Lucchitta, Ivo, McDougall, Kristin, Metzger, D.G., Morgan, Paul, Smith, G.R., and Chernoff, Barry, 2001, The Bouse Formation and post-Miocene uplift of the Colorado Plateau, in Young, R.A., and Spamer, E.E., eds., Colorado River-origin and evolution: Grand Canyon, Ariz., Grand Canyon Association, p. $173-178$.

Mariano, John, Helferty, M.G., and Gage, T.B., 1986, Bouguer and isostatic residual gravity maps of the Colorado River region, including the Kingman, Needles, Salton Sea, and El Centro quadrangles: U.S. Geological Survey Open-File Report 86-347, scale 1:250,000.

Martin, D.L., Krummenacher, Daniel, and Frost, E.G., 1982, K-Ar geochronologic record of Mesozoic and Tertiary tectonics of the Big Maria-Little Maria-Riverside Mountains terrane, in Frost, E.G., and Martin, D.L., eds., Mesozoic-Cenozoic tectonic evolution of the Colorado River region, California, Arizona, and Nevada: San Diego, Calif., Cordilleran Publishers, p. 519-557.

Metzger, D.G., 1968, The Bouse Formation (Pliocene) of the Parker-Blythe-Cibola area, Arizona and California, in Geological Survey Research 1968: U.S. Geological Survey Professional Paper 600-D, p. D126-D136.

Metzger, D.G., Loeltz, O.J., and Irelna, Burdge, 1973, Geohydrology of the Parker-Blythe-Cibola area, Arizona and California: U.S. Geological Survey Professional Paper 486-G, 130 p.

Patchett, P.J., and Spencer, J.E., 2001, Application of Sr isotopes to the hydrology of the Colorado River system waters and potentially related Neogene sedimentary formations, in Young, R.A., and Spamer, E.E., eds., Colorado River-origin and evolution: Grand Canyon, Ariz., Grand Canyon Association, p. $167-171$.

Pelka, G.J., 1973, Geology of the McCoy and Palen Mountains, southeastern California: Santa Barbara, University of California, Ph.D. dissertation, $162 \mathrm{p}$.

Powell, R.E., 1993, Balanced palinspastic reconstruction of pre-late Cenozoic paleogeology, southern California-geologic and kinematic constraints on evolution of the San Andreas fault system, in Powell, R.E., Weldon, R.J., III, and Matti, J.C., eds., The San Andreas fault system-displacement, palinspastic reconstruction, and geologic evolution: Geological Society of America Memoir 178, p. 1-106.

Purcell, Charles, and Miller, D.G., 1980, Grabens along the lower Colorado River, California and Arizona, in Fife, D.L., and Brown, A.R., eds., Geology and mineral wealth of the California desert: Santa Ana, Calif., South Coast Geological Society, p. 475-484.

Reynolds, S.J., Spencer, J.E., Richard, S.M., and Laubach, S.E., 1986, Mesozoic structures in west-central Arizona, in Beatty, Barbara, and Wilkinson, P.A.K., eds., Frontiers in geology and ore deposits of Arizona and the southwest: Arizona Geological Society Digest, v. 16, p. 35-51.

Richard, S.M., 1993, Palinspastic reconstruction of southeastern California and southwestern Arizona for the middle Miocene: Tectonics, v. 12, p. 830-854.

Richard, S.M., Ballard, S.N., Boettcher, S.S., Hamilton, W.B., Hoisch, T.D., and Tosdal, R.M., 1994, Mesozoic tectonics of the Maria belt, west-central Arizona and southeastern California, in McGill, S.F., and Ross, T.M., eds., Geological investigations of an active margin (guidebook for Geological Society of America Cordilleran Section $27^{\text {th }}$ Annual Meeting): Redlands, Calif., San Bernardino County Museum Association, p. 272-292.

Rotstein, Yair, Combs, Jim, and Biehler, Shawn, 1976, Gravity investigation in the southeastern Mojave Desert, California: Geological Society of America Bulletin, v. 87, p. 981-993.

Saleeby, J.B., and Busby-Spera, Cathy, 1992, Early Mesozoic tectonic evolution of the western U.S. Cordillera, in Burchfiel, B.C., Lipman, P.W., and Zoback, M.L., eds., The Cordilleran orogen-conterminous U.S.: Boulder, Col., Geological Society of America, The Geology of North America, v. G-3, p. 107-168. 
Smith, P.B., 1970, New evidence for a Pliocene marine embayment along the lower Colorado River area, California and Arizona: Geological Society of America Bulletin, v. 81, p. 1411-1420.

Spencer, J.E., and Patchett, P.J., 1997, Sr isotopic evidence for a lacustrine origin for the upper Miocene to Pliocene Bouse Formation, lower Colorado River trough, and implications for timing of Colorado Plateau uplift: Geological Society of America Bulletin, v. 109, p. 767-778.

Spencer, J.E., and Pearthree, P.A., 2001, Headward erosion versus closed-basin spillover as alternative causes of Neogene capture of the ancestral Colorado River by the Gulf of California, in Young, R.A., and Spamer, E.E., eds., Colorado River-origin and evolution: Grand Canyon, Ariz., Grand Canyon Association, p. 215-219.

Spencer, J.E., Peters, Lisa, McIntosh, W.C., and Patchett, P.J., 2001, ${ }^{40} \mathrm{Ar} /{ }^{39} \mathrm{Ar}$ geochronology of the Hualapai Limestone and Bouse Formation and implications for the age of the lower Colorado River, in Young, R.A., and Spamer, E.E., eds., Colorado River-origin and evolution: Grand Canyon, Ariz., Grand Canyon Association, p. 89-91.

Stone, Paul, 1990, Preliminary geologic map of the Blythe 30' by 60' quadrangle, California and Arizona: U.S. Geological Survey Open-File Report 90-497, scale 1:100,000.

Stone, Paul, Howard, K.A., and Hamilton, Warren, 1983, Correlation of metamorphosed Paleozoic strata of the southeastern Mojave Desert region, California and Arizona: Geological Society of America Bulletin, v. 94, p. 1135-1147.

Stone, Paul, and Pelka, G.J., 1989, Geologic map of the Palen-McCoy Wilderness Study Area and vicinity, Riverside County, California: U.S. Geological Survey Miscellaneous Field Studies Map MF-2092, scale 1:62,500.

Stone, Paul, Page, V.M., Hamilton, Warren, and Howard, K.A., 1987, Cretaceous age of the upper part of the McCoy Mountains Formation, southeastern California and southwestern Arizona, and its tectonic significance-reconciliation of paleobotanical and paleomagnetic evidence: Geology, v. 15, p. 561564.

Tosdal, R.M., 1988, Mesozoic rock units along the Late Cretaceous Mule Mountains thrust system, southeastern California and southwestern Arizona: Santa Barbara, University of California, Ph.D. dissertation, $365 \mathrm{p}$.

Tosdal, R.M., 1990, Constraints on the tectonics of the Mule Mountains thrust system, southeast California and southwest Arizona: Journal of Geophysical Research, v. 95, no. B12, p. 20,025-20,048.

Tosdal, R.M., Haxel, G.B, and Wright, J.E., 1989, Jurassic geology of the Sonoran Desert region, southern Arizona, southeastern California, and northernmost Sonora: Construction of a continental-margin magmatic arc, in Jenney, J.P., and Reynolds., S.J., eds., Geologic evolution of Arizona: Arizona Geological Society Digest 17, p. 397-434.

Tosdal, R.M., and Stone, Paul, 1994, Stratigraphic relations and U-Pb geochronology of the Upper Cretaceous upper McCoy Mountains Formation, southwestern Arizona: Geological Society of America Bulletin, v. 106, p. 476-491.

Wooden, J.L., and Miller, D.M., 1990, Chronologic and isotopic framework for Early Proterozoic crustal evolution in the eastern Mojave Desert region, SE California: Journal of Geophysical Research, v. 95, no. B12, p. 20,133-20,146.

Zimbelman, J.R., and Williams, S.H., 2002, Geochemical indicators of separate sources for eolian sands in the eastern Mojave Desert, California, and western Arizona: Geological Society of America Bulletin, v. 114, p. 490-496. 